\title{
Unsafe abortion: a patriarchal and racialized picture of women's poverty
}

\section{Mirla Cisne ${ }^{1}$}

https://orcid.org/0000-0002-4654-8464

\author{
Viviane Vaz Castro ${ }^{1}$ \\ https://orcid.org/0000-0003-1803-8210
}

\section{Giulia Maria Jenelle Cavalcante de Oliveira ${ }^{1}$ \\ https://orcid.org/0000-0002-4834-7500}

${ }^{1}$ Universidade do Estado do Rio Grande do Norte, Departamento de Serviço Social, Programa de Pós-Graduação em Serviço Social e Direitos Sociais, Mossoró, RN, Brazil

\section{Unsafe abortion: a patriarchal and racialized picture of women's poverty}

Abstract: This article aims to analyze how the reality of criminalized abortion reinforces inequalities of gender, race/ethnicity, and class, which are co-produced within the context of sexage, understood here as the appropriation of women by men, reducing them to the status of thing. The bibliographic and documentary research was carried out, from the perspective of materialistic, historical and dialectical analysis. The main conclusion is that criminalization reinforces the logic of social inequalities in Brazil and the world. This is because poor and black women are the most affected, those who die the most, and because almost all unsafe abortions in the world occur in the peripheric economies. Thus, the consequences of criminalized abortion, whether moral, health or economic, mainly impact poor, black, young women living in peripheral economies.

Keywords: Abortion. Sexage. Patriarchy. Racism. Social class.

Submitted on February 15, 2018. Approved on May 25, 2018. Reviewed on June 19, 2018.

\section{ब०} which permits use, distribution, and reproduction in any medium, since it's for non-commercial purposes, and provided you give appropriate credit to the original author(s) and the source, provide a link to the Creative Commons license, and indicate if changes were made. 


\section{Introduction}

In ancient times the practice of abortion was considered natural and not understood as a crime, as opposed to adultery. It was only from the nineteenth century that abortion became prohibited in the West. This prohibition began with the influence of the Catholic Church and its patriarchal bases, especially in Latin America. Since then, abortion has become the target of strong polemics in society.

An age-old practice, marked by religious fundamentalisms, prejudices, and patriarchal, race and class violence and inequalities, makes abortion an issue that is not only controversial but one of the most challenging issues facing the feminist movement. Critically analyzing unsafe and illegal abortion is to seek to uncover the smoke walls of the patriarchal ideology that massacres and criminalizes women, especially the poor and the black. The material basis of this ideology rests on the appropriation of women's time, labor, and bodies (and of the products of their bodies) as a result of the relations of sexage $e^{1}$ that reduces women to the status of thing (Guillaumin, 2014).

Because abortion is illegal, criminalized and brings a heavy sense of blame towards women, it is veiled although common - practice. Abortion is a complex issue, surrounded by dominant ideologies and social inequalities, and it is essential to theoretically and critically reflect on it, contributing to the defense of women's lives. Thus, the objective of this article is to analyze how the reality of criminalized abortion shows and reinforces the inequalities of sex, race/ethnicity, and class, which are co-produced within the context of sexage, that is, the appropriation of women by men. The study carries out bibliographic and documental research, based on reports from the Brazilian government, research institutes and international organizations, collecting data on the reality of abortion in Brazil and worldwide.

As a method of analysis to carry out this research, we adopted the dialectical historical materialism, considering that the object of study demands to be apprehended in a perspective of totality, seeking its sociohistorical and economic determinations in the dialectical and inseparable web of social relations of sex, race and class, and their legal and ideological representations. Moreover, the choice for this method is because we understand that reality is in constant movement by the contradictions, conflicts, and struggles, it is full of possibilities for transformation. In this sense, we analyze abortion as an expression of the social issue to be faced with ethical-political commitment in defense of freedom, autonomy and social equality for women.

Women use different methods in the practice of abortion, and sometimes they do it alone. The discovery of pregnancy for a woman is different, and they are often submitted to ill-treatment in hospitals. Finally, there are different histories and paths (Diniz \& Medeiros, 2012), because human life is not exact and there are several elements that determine our material conditions of existence, our subjectivity, and our choices. What we want to point out here is that race/ethnicity and class situation make women who are in a situation to have an abortion, to follow different paths, with more or less pain, more or less institutional and obstetric deaths and violence. This needs to be understood to take account of the consequences of the criminalization of abortion. After all, who are the women most affected by this criminalization? All these questions are discussed with the contribution of the perspective of consubstantiality and the coextensivity of social relations of sex, race, and class, as we shall see below.

\section{Abortion and the social relations of sex, race/ethnicity and class}

We start from the understanding that the material and subjective life conditions of women and the place they occupy in class society are fundamental elements to understand the universe of abortion in addition to moral and religious arguments. In this sense, we consider the sexual division of labor a central element, understanding it as a:

[...] form of social division of labor resulting from social relations of sex; this form is historically adapted to each society. The characteristics observed are the presence of men in the sphere of production and women in the sphere of reproduction. At the same time, the roles of high added social value are occupied by men (such as political, religious, military). (Kergoat, 2009, p. 67).

This division of labor assigns to women the responsibility for domestic work, family care and all the tasks necessary to reproduce the workforce, and it seems to be a natural destination for all of them (Saffioti, 2013). With this sexual division of labor, "[...] in doing unpaid domestic work and being largely responsible for childcare, women are performing functions that are essential to the continued and uniform functioning of the capitalist system." (Veloso, 2001, p. 84). 
Based on this dynamic, it is necessary to think of the possibility of motherhood, since it poses difficulties for women regarding their job position - especially if they are informal workers and do not have the right to maternity leave and other labor rights. The possibility of motherhood often results in the return to the domestic space to raise the children, since this responsibility is attributed almost uniquely to women and not shared with most men (Cisne, 2012). In other words, with the sexual division of labor in a patriarchal society - which causes overexploitation of the female workforce exposed to the most precarious and low-paid jobs - associated with the work of taking care of the physical, emotional and educational needs of the children, subjects women to an extensive, intensive and intermittent daily workload (Ávila, 2009). It is essential to observe that some women drop out of school to take care of their children, which results in devaluation of their work due to both low level of education and sex oppression (Saffioti, 2013). In this sense, it is not difficult to understand why so many women resort to abortion, often using means that are unsafe and harmful to their physical and mental health.

For women, motherhood results in immediate reversal of their life priorities, alter their daily lives, and assigns them enormous individual responsibilities, as there is the social burden of assuming the primary task of caring for their children and the home. According to Saffioti (2013, p. 86):

Motherhood cannot, therefore, be seen as an exclusive burden on women. Since society is interested in the birth and socialization of new generations as a condition of its survival, it must pay at least part of the price. It means finding satisfactory solutions to the problems of professional nature that motherhood creates for women.

It is necessary to promote another analysis on motherhood since in this context the impacts on women's lives are profound and help to explain why the practice of abortion is so old, ordinary and current. After all, what precedes any situation of voluntary abortion is an unwanted or unplanned pregnancy.

At the same time that patriarchal motherhood imposes such conditions on women, they are subject to sexual obligations, in a relationship mediated by marriage, and which permeates the appropriation of women by men in various dimensions, whether in the use of women's time and work or even the appropriation of women as subjects (Guillaumin, 2014). According to the author:

This is not by virtue of a direct contract of appropriation as in the case of the wife (whose naked appropriation is demonstrated in the legal obligation - first and foremost - of sexual service), but as function of the general appropriation of the class of women, which implies that their time (their work) may be disposed of without contractual compensation, and may be generally and indiscriminately disposed of. It is as if the wife is actually owned by the husband, and each man has the enjoyment of the class of women, and particularly each man who has acquired the private use of one of them. (Guillaumin, 2014, p. 35).

Thus, women are appropriated as things by men, collectively and privately (by marriage), enabling the possession of their lives, their bodies and the products of their bodies (Guillaumin, 2014). On this appropriation of the products of the body, the author points out:

[...] the still present proof of the appropriation of the products of the body is that in marriage the number of children is not subject of contract, is not fixed or subjected to the wife's approval. The absence for most women of the real possibility of contraception and abortion is the result of this. The wife must and will bear all the children that her husband wants to impose on her. And if the husband exceeds what is convenient for him, he will put all the responsibility on the wife, who must give him everything that he wants, but only what he wants. The status of abortion, clandestine for such a long time, existing without existing, confirmed this relationship, abortion being the recourse of women whose husbands did not want the child, as much as the recourse of women who did not want the child themselves. (Guillaumin, 2014, p. 36)

From this perspective, the decision on the products of the body - such as having children or not, and how many - pervades the relations of domination and inequality between men and women (Guillaumin, 2014). For some, having children is a sign of masculine virility, generates heirs and has to do with men's honor. How is it possible to guarantee sexual and reproductive rights for women in this scenario in which their lives, their bodies, and the products of their bodies remain under men's possession and decision?

It is in this context that the decision to be a mother or not, at a certain point in her life, is defined by the woman. Faced with this, several women resort to abortion, poor or not, for different reasons. However, as observed from data collected in some of the reports used in this study, this experience is unequally lived among them, according to their class and race/ethnicity - elements that also define their material living conditions and the possibility of reproducing without going through deprivation. 
The Retrato das desigualdades de gênero e raça [Portrait of Gender and Race Inequalities] report of the Applied Economic Research Institute (IPEA) states that:

\begin{abstract}
The data show a clear occupational segmentation, related to both gender and race. Women, especially black women, are more concentrated in the social services sector (about $34 \%$ of the female workforce), a segment encompassing care services in the broadest sense (education, health, social and domestic services). As for men, especially black men, they are overrepresented in the segment of construction (in 2009, this sector employed about $13 \%$ of all men and less than $1 \%$ of the female population). (Instituto de Pesquisa Econômica Aplicada [IPEA], 2011, p. 27).
\end{abstract}

Attention must be paid to the particularities of the Brazilian socio-historical formation, strongly marked by the period of slavery, which says much about the racial division of labor that persists, as evidenced in IPEA's report. Racism materializes in the lives of black women who occupy the most precarious, informal, low-paid and high-turnover jobs.

The work considered to be naturally feminine, related to care and social reproduction, executed in the private sphere and associated to the family's maintenance, results that $83 \%$ of the world's domestic jobs are occupied by women, and $45 \%$ of these women are not entitled to weekly rest periods or vacation pay ("Mundo tem mais," 2013). Also, the United Nations (UN, 2011) report shows that women form $70 \%$ of the world's poor population.

In this context, we consider as crucial the analysis provided by the theoretical-methodological perspective of the consubstantiality and coextensivity of the social relations of sex, race/ethnicity, and class, understanding them in a whole and dialectical way, in which one modifies and depends on the other (Cisne, 2014). That is to say, social relations " $[. .$.$] form a knot that cannot be unleashed at the level of social practices, but only from the perspective of$ sociological analysis.” (Kergoat, 2010,p. 94). About consubstantiality and coextensivity, Kergoat (2010,p. 100) explains:

The idea of consubstantiality [...] does not imply that everything is connected to everything; it is only a way of reading social reality. It is the dynamic and complex interlocking of the set of social relations, each imprinting its mark on the others, adjusting to the others and building reciprocally. [...] As for coextensivity, it points to the dynamism of social relations. The concept seeks to explain the fact that social relations produce each other.

With this perspective of analysis, abortion cannot be thought from a single social relation, but from the totality of social life, in which the dimensions of sex, race/ethnicity and class are crucial for the decision and the paths of different women who have aborted or who may abort at some point in their lives. Based on this reflection, we understand that thinking the contradictions of this practice so old and common in the life of women requires to consider the inequalities that structure the patriarchal-racist-capitalist society, which is crossed by the sexual and racial division of labor and its concrete effects in the women's daily lives. In this sense, consubstantiality offers us a condition to critically analyze data on the reality of abortion, showing that its criminalization shows and reinforces the inequalities of gender, race/ethnicity, and class.

If Angela Davis (2016, p. 205) is emphatic and accurate in saying that "the historical record of this movement [for the right to abortion and birth control] leaves much to be desired in the realm of challenges to racism and class exploitation", and it is up to us feminist activists and researchers to look for ways to advance in this direction. Thus, we agree with Kergoat's (2010, p. 103) statement “[...] analyzing and better understanding social relations and their interweaving, and elaborating a method to think about these relations is to take a step towards overcoming them." Therefore, it is not enough to broaden the debate on the importance and urgency of legalizing abortion, or even increase women's studies, even though this is important. It is time to engage in the political struggle, undertaking actions that move towards class, race, and gender emancipation.

\title{
Unsafe abortion and criminalization of women: why and for whom?
}

The World Health Organization (WHO, 2013) estimates that there are around 22 million unsafe abortions per year in the world, $98 \%$ of them in peripheral economies. These abortions result in 47,000 deaths per year, and two-thirds of them are in Africa (WHO, 2016). Also, three out of four abortions in peripheral economies can be considered as unsafe (WHO, 2013). These estimates indicate the historical inequalities between countries, brought about by colonialism, the unequal economic exchange between the metropole and colony, and more recently by imperialism (Mandel, 1982). Latin America and Africa suffered from the "uneven and combined development"2 (Mandel, 1982, pp. 243-244) of international capitalism in the period of European colonization. 
It is possible to observe in these two continents, high rates of extraction of surplus value, privileging the colonial metropolis. This historical antecedent has repercussions to this day, manifested in issues such as abortion, poverty, unemployment, and hunger in these countries, for example. The truth is that the living conditions of the population in Europe are better at the expense of exploitation and the precarious living conditions of workers living in peripheral economies.

It is not possible to carry out a socio-historical characterization of these continents or their countries, but it is necessary to draw attention to the alarming situation of abortion in the African continent. African women aged $15-49$ represent $14 \%$ of women worldwide and $62 \%$ of all deaths caused by abortion complications. One of the causes of these data is the low access and consumption of contraceptive methods, which indicates the inequalities, and the humanitarian and civilization crisis (WHO, 2013).

Angela Davis (2016, p. 207), in Mulheres, raça e classe [Women, Race and Class], points out that in New York in the 1970s, "[about] 80 percent of deaths caused by illegal abortions involved Black and Puerto Rican women", and says:

\begin{abstract}
When Black and Latina women resort to abortions in such large numbers, the stories they tell are not so much about their desire to be free of their pregnancy, but rather about the miserable social conditions which dissuade them from bringing new lives into the world. Black women have been aborting themselves since the earliest days of slavery. Many slave women refused to bring children into a world of interminable forced labor, where chains and floggings and sexual abuse for women were the everyday conditions of life. (Davis, 2016, p. 207).
\end{abstract}

Thus, racism and these women's living conditions made it impossible for them to live motherhood, because the despair for the possibility of seeing their sons and daughters under the same inhuman conditions sometimes prevailed, even if it also cost their own lives.

The inequalities operated by the capital system at the international level and its appropriations of patriarchy and racism are expressed in the sexual and reproductive life of women, deepening the dimension of oppression and exploitation over them. For us, understanding the material and subjective determinations of women (and of different women, in different contexts) is essential for thinking about the issue of abortion.

\title{
Abortion in Brazil: a socio-juridical analysis beyond the legislation
}

There are over one million unsafe abortions per year in Brazil (Brasil, 2009, 2014). There are approximately 250 thousand admissions due to medical complications resulting from illegal, and therefore unsafe, practice. As a result, abortion is one of the leading causes of maternal mortality in the country, with post-abortion curettage being one of the most performed obstetric procedures by the Brazilian National Health System (SUS) (Brasil, 2014). According to the WHO (2016), it is cheaper for the state to guarantee legal abortion performed by health professionals and under appropriate conditions (with access to medicines and in a hospital) - which is a procedure considered low risk than to treat the complications of illegal abortion. As for the profile of the women who underwent an abortion, the Ministry of Health (Brasil, 2009) shows that the majority of them already have children, are Catholic and are in a stable relationship with a partner. These characteristics tell us that abortion is much more common than previously thought.

The Ministry of Health, through a technical norm on humanized attention to abortion, further states that:

Vulnerabilities such as gender inequalities, cultural and religious norms, inequalities in access to education, and multiple poverty dimensions - such as the lack of economic resources and alternatives, the difficulty of access to information and human rights, and unhealthiness - lead to the fact that unsafe abortion reaches and sacrifices, in a more devastating way, women from poor and marginalized communities. (Brasil, 2014).

Data corroborate the analysis of the Ministry of Health when showing that the majority of women who submit to unsafe abortion and are hospitalized are young and poor (Brasil, 2009). Regarding unsafe abortions, an alternative report to the Committee on the Elimination of Discrimination against Women (CEDAW) states that "[...] black women have a three times greater risk of dying from unsafe abortion than women [...]" (Comitê Latino Americano e do Caribe para a Defesa dos Direitos da Mulher et al., 2012, p. 14) and that "[...] maternal deaths that occur mostly in women of lower social classes with low education and low wages, focuses in a particular way on black women." (Comitê Latino Americano e do Caribe para a Defesa dos Direitos da Mulher et al., 2012, p. 18). 
The data on abortion somehow show that criminalization affects the more vulnerable segments of society, although the practice is common among all populations, in different ways according to class and race. As pointed out by Diniz and Medeiros (2010, p. 962):

The proportion of women who have had abortions increases with age. This proportion varies from $6 \%$ for women aged 18 to 19 years, to $22 \%$ among women aged 35 to 39 years old. This shows how abortion is a common phenomenon in women's reproductive lives. At the end of their reproductive life, more than a fifth of women in urban areas in Brazil had an abortion.

These data highlight how abortion has sometimes been the only alternative to unwanted pregnancies, with women using unsafe methods that can result in various complications in their lives and reproductive health.

The work of Diniz and Medeiros (2012) shows several contradictions of the patriarchal-racist-capitalist system: at the same time that the results show that some of the women who underwent abortion had some assistance, the majority of them who were alone in the procedure are black and have low educational level; if the main method used for abortion was $\mathrm{Cytotec}^{3}$, most young women still use less safe methods and are the ones that suffer most from ill-treatment in hospitals, practice characterized as institutional obstetric violence, motivated by patriarchal religious fundamentalisms. Also, the authors point out that the most common abortion method used by black adolescents with low educational level is the use of teas, herbs, and liquids, ending the procedure in hospitals. Another important issue detected is related to the discovery of pregnancy: the authors showed that among the women who did not use any method that could confirm the pregnancy, most of them are black and found out about the pregnancy based on changes in their body. Delay in detecting pregnancy also delays the abortion procedure, which increases the risk to their lives.

\section{[...] criminalized abortion}

shows and reinforces the inequalities of sex, race/

\section{ethnicity, and class, which are}

co-produced within the context

of sexage, that is, the

appropriation of women by

men.

It is possible to observe, therefore, that the reality of unsafe abortion in the country and the world is a demonstration of gender, race/ethnicity and class inequalities. It is clear that the criminalization of abortion reaches more directly to a specific group, thus increasing social discrimination and deepening the social issue. Poor and black women are appropriated and dispossessed ${ }^{4}$ by the capitalistpatriarchal-racist rules, suffering privations and violations, from the difficulty of insertion into the world of work, due to the sexual and racial division of labor, to their subjective right to motherhood.

On the other hand, there are a series of bills that aim to further intensify the criminalization of abortion, withdrawing the rights provided in specific cases. As an example, there is a proposed amendment to the Brazilian Constitution (PEC) 181 (Proposta de Emenda à Constituição n. 181-A, 2015), which, under the guise of providing an increase in maternity leave for women who give birth to preterm infants, infiltrates the expression in the constitutional text "desde a concepção" [from conception], in section 3 of Article 1, which refers to the fundamental principles of the Constitution, and in Article 5, which provides for fundamental rights and guarantees ${ }^{5}$. Another example is the bill 5069/13 (Projeto de lei n. 5.069, 2013) that alters the Brazilian Criminal Code (CPB), typifying as a crime against life the mere announcement of an abortive measure and provides specific penalties for those who induce pregnant women to abortion. If approved, the advances of existing exceptions to criminalization will suffer a setback. Also, new types of crime can be typified, and again, the group most affected will be poor and black women, deepening inequalities.

The eighteen deputies who voted for PEC 181 are from the religious parliamentary group, which reinforces the religious influence in Latin America. In this scenario, the woman's body becomes a currency of exchange; it becomes part of a trap created by the legislative branch. Therefore, the struggle of women ceases to be, in no small extent, for the extension of rights and happens to be to protect them.

Thus, Brazil experiences a State that criminalizes women much more than it guarantees their rights. It is a State that does not challenge the inequalities and exacerbates and daily damages the principle of secularity. The promotion of the ideology of illegality, the very law, and bills that criminalize abortion, under the argument of upholding intrauterine life, actually disregards the lives of women.

In this work, we advocate for the argument that corroborates the understanding of the Brazilian Supreme Court (STF) in the judgment of the Habeas Corpus (HC) 124306. According to the judges, there is damage to 
proportionality when abortion is criminalized to the detriment of the dignity of the woman. The measure of criminalization is not suitable to protect the fetus, therefore, does not impact on the numbers of abortions.

In this case, the STF presented a possible fourth exception ${ }^{6}$ to the criminalization of abortion, namely, the interruption of pregnancy in the first trimester of pregnancy, caused by the pregnant woman herself (Article 124 of the $\mathrm{CPB}$ ) or with her consent (Article 126 of the $\mathrm{CPB}$ ), would also not be classified as crime (Decretolei n. 2.848, 1940).

According to Barroso, one of the judges of the STF, in order for a conduct to be compatible with the Constitution, criminalization must fulfill three requirements: the typology of crime must be related to protecting a relevant legal asset; the incriminated behavior cannot constitute a legitimate exercise of a fundamental right, and there must be proportionality between the action taken and the state reaction (HC 124306/RJ, first judge of the case Marco Aurélio, case forwarded to judge Luis Roberto Barroso, decision returned on November 29, 2016. Info 849).

It is incontestable that the life of women is a relevant legal right, that is, it must be protected by the national legal order. Criminalizing abortion before the first trimester violates some fundamental rights, including women's autonomy, physical and mental integrity, sexual and reproductive rights, gender equality and, above all, increased social discrimination and the blatant impact on poor and black women

In a survey conducted by the Defensoria Pública do Estado do Rio de Janeiro [Public Defender Office of Rio de Janeiro] (2017) analyzing criminal cases related to the crime of abortion pending before the Court of Justice of Rio de Janeiro, from 2005 to 2017, the profile of the criminalized women was outlined. As expected in a society marked by the regime of exploitation of capital, slavery, patriarchy and sexual and racial division of labor, the profile identified is the same as in other parts of the world: black, mothers, poor and without criminal records. Considering this was a state-level survey, the results obtained in such a reduced scope may be subject to criticisms. However, it is important to stress that the state of Rio de Janeiro is not one of the regions most exploited by the uneven and unequal capitalism, which may indicate that the issue may be more severe in the interior of the country.

We do not take away the importance of advances regarding legislation and the acts of the Brazilian judiciary, which provided exceptions to the criminalization of abortion (particularly when afforded the habeas corpus HC 124306), and were necessary for the construction of a future where abortion will be decriminalized or even legalized. In our view, however, without a change in structures, and dialectically in superstructures, from a capitalist society that promotes class, gender and race inequalities to a socialist with the aim of eliminating social inequalities, it will not be possible to achieve human emancipation, necessary to guarantee substantive equality and freedom (Mészáros, 2002).

\section{Final considerations}

Women are subject to a practically uninterrupted working day, as a result of a sexual division of labor that attributes to them the responsibility for tasks related to social reproduction such as domestic work and taking care and educating the children. Also, the women's attributions are devalued, they perceive lower wages and occupy precarious jobs, especially if they are black women. Gender inequalities in the world of work and, among women, the ethnic and racial inequalities, are elements that hinder the capacity of reproduction for all women in the same conditions.

Subject to the appropriation of their time, their body and the product of their body by men, they live the condition of sexual obligation, due to the relations of sexage (Guillaumin, 2014). The relation of appropriation over women makes it impossible for women to fully realize their sexual and reproductive rights, limiting their ability to decide with whom and when to become pregnant, and how many children to have.

The context of gender, race/ethnicity and class inequalities is evidenced in the data on abortion in Brazil and worldwide, and its criminalization, at the same time as it is determined by these inequalities, also strengthens them.

Against this backdrop and analyzing the contradictions shown by data on abortion, there would be no other possible investigation path than the theoretical-methodological choice of consubstantiality and coextensivity of the social relations of gender, race/ethnicity, and class, in a dynamic where these relations are mutually produced and co-produced.

In a brief analysis of the analyzed data, it is possible to say that the criminalization reinforces the logic of social inequalities in Brazil and worldwide. Almost all unsafe abortions happen in peripheral economies. The poor, young, black women, living in peripheral economies are the most affected and those who die the most. They are the ones suffering the highest moral, health or economic consequences of illegal abortion.

Moreover, the prohibition of abortion does not make it disappear or diminish its practice, neither does it provide conditions of integral health to the women nor appropriate and humanized care. 
Finally, we agree with Angela Davis (2016, p. 205), when she mentions that “[...] birth control - individual choice, safe contraceptive methods, as well as abortions when necessary - is a fundamental prerequisite for the emancipation of women." In other words, being a mother is not destiny or a biological contingency, it must be more than a natural possibility, it must be a decision planned and desired by the woman, respecting her autonomy and real freedom of choice over her own life. Therefore, it is fundamental to build a society that allows this autonomy and freedom, which requires overcoming the patriarchal-racist-capitalist system for the guarantee of human emancipation.

\section{References}

Agências da ONU divulgam nota sobre PEC 181/15. (2017, November 20). Retrieved from https://nacoesunidas.org/agencias-da-onumanifestam-preocupacao-com-pec

Ávila, M. M. B. (2009). O tempo de trabalho das empregadas domésticas: tensões entre dominação/exploração e resistência (Tese de doutorado). Programa de Pós-Graduação em Sociologia, Universidade Federal de Pernambuco, Recife, PE, Brasil.

Brasil. (2009). 20 anos de pesquisas sobre aborto no Brasil. Brasília: Ministério da Saúde.

Brasil. (2014). Atenção Humanizada ao Abortamento: norma técnica (2nd ed.). Brasília: Ministério da Saúde.

Cisne, M. (2012). Gênero, divisão sexual do trabalho e Serviço Social. São Paulo: Outras Expressões.

Cisne, M. (2014). Feminismo e consciência de classe no Brasil. São Paulo: Cortez.

Comitê Latino Americano e do Caribe para a Defesa dos Direitos da Mulher, IPAS, Rede Nacional Feminista de Saúde, Direitos Sexuais e Direitos Reprodutivos, GESTOS Soropositividade Comunicação e Gênero, Ação Educativa, ECOS Comunicação e Sexualidade, ... . Coletivo Feminino Plural. (2012, January). Relatório Alternativo ao Relatório Brasileiro 2006-2009: Comitê CEDAW [Report]. Retrieved from https://yaeshora.cladem.org/images/estiempo/brasil/pdf/1Enero_-_Brasil_-_RA_CEDAW_2012.pdf

Davis, A. (2016) Mulheres, raça e classe. São Paulo: Boitempo.

Decreto-lei n. 2.848, de 7 de dezembro de 1940. Código Penal. Retrieved from https://www.planalto.gov.br/ccivil_03/Decreto-Lei/ Del2848.htm

Defensoria Pública do Estado do Rio de Janeiro. (2017). DPRJ traça perfil de mulheres criminalizadas pela prática do aborto. Rio de Janeiro: DPRJ. Retrieved from http://www.defensoria.rj.def.br/noticia/detalhes/5372-DPRJ-aponta-perfil-da-mulher-criminalizada-pelapratica-do-aborto

Diniz, D., \& Medeiros, M. (2010). Aborto no Brasil: uma pesquisa domiciliar com técnica de urna. Ciência e Saúde Coletiva, 15(Suppl. 1), 959-966. Retrieved from http://www.scielo.br/pdf/csc/v15s1/002.pdf

Diniz, D., \& Medeiros, M. (2012). Itinerários e métodos do aborto ilegal em cinco capitais brasileiras. Ciência e Saúde Coletiva, 17(7), 1671-1681. Retrieved from http://www.scielo.br/pdf/csc/v17n7/02.pdf

Guillaumin, C. (2014). Prática do poder e ideia de natureza. In V. Ferreira, M. B. Ávila, J. Falquet, \& M. Abreu (Orgs.), Patriarcado Desvendado: teorias de três feministas materialistas: Colette Guillaumin, Paola Tabet e Nicole-Claude Mathieu (pp. 27-100). Recife: SOS Corpo.

Harvey, D. (2004). O Novo Imperialismo. São Paulo: Loyola.

Instituto de Pesquisa Econômica Aplicada. (2011). Retrato das desigualdades de gênero e raça. Retrieved from http://www.ipea.gov.br/ retrato/pdf/revista.pdf

Kergoat, D. (2009). Divisão sexual do trabalho e relações sociais de sexo. In H. Hirata, F. Laborie, H. Le Doaré, \& D. Senotier (Orgs.), Dicionário crítico do feminismo (pp. 67-75). São Paulo: UNESP.

Kergoat, D. (2010). Dinâmica e consubstancialidade das relações sociais. Novos Estudos Cebrap, (86).

Mandel, E. (1982). O capitalismo tardio: os economistas. São Paulo: Abril Cultural.

Mészáros, I. (2002). Para além do capital. São Paulo: Boitempo.

Mundo tem mais de 52 milhões de trabalhadores domésticos, calcula OIT. (2013, January 9). Retrieved from https://nacoesunidas.org/ mundo-tem-mais-de-52-milhoes-de-trabalhadores-domesticos-calcula-oit/

Projeto de lei n. 5.069, de 2013. Acrescenta o art. 127-A ao Decreto-lei nº 2.848, de 7 de dezembro de 1940 - Código Penal. Retrieved from http://www.camara.gov.br/proposicoesWeb/prop_mostrarintegra?codteor=1061163\&filename=PL+5069/2013

Proposta de Emenda à Constituição n. 181-A, de 2015. Retrieved from http://www.camara.gov.br/proposicoesWeb/ fichadetramitacao?idProposicao $=2075449$

Saffioti, H. I. B. (2013). A mulher na sociedade de classes: mito e realidade (3rd ed.). São Paulo: Expressão Popular.

United Nations. (2011). Annual Report 2011-2012. United Nations entity for gender equality and the empowerment of women. Retrieved from http://www.unwomen.org/ /media/Headquarters/Attachments/Sections/Library/Publications/2012/UN-Women-AR-2012\%20pdf.pdf Veloso, R. (2001). No caminho de uma reflexão sobre Serviço Social e Gênero. Revista Praia Vermelha Estudos de Política e Teoria Social, 2(4).

World Health Organization. (2013). Abortamento seguro: orientação técnica e de políticas para sistemas de saúde (2nd ed.). Retrieved from http://apps.who.int/iris/bitstream/10665/70914/7/9789248548437_por.pdf

World Health Organization. (2016, February 19). Prevención del aborto peligroso. Retrieved from http://www.who.int/mediacentre/ factsheets/fs $388 /$ es/ 


\section{Notes}

1 Category coined by Guillaumin (2014), in analogy to the terms slavery and servitude, which designates, in particular, the process of appropriation of women and reducing them to the status of thing.

2 The theory of the uneven and combined development shows the imperialist relations between metropoles and colonies in the international capitalism development. Basically, for the wealth of the colonialist European bourgeois and the evolvement of capitalism, the colonies were exploited through the extraction of raw material and use of lower cost workforce, in a dynamic of uneven exchange and overexploitation of colonized peoples. See Mandel's work Late Capitalism (Portuguese version consulted for this study O capitalismo tardio, 1982).

3 Name also used to refer to misoprostol.

4 On dispossession, see Harvey (2004).

5 UN agencies manifested their concern, in December 2017, about the eventual approval of the Constitutional amendment, saying that "[...] denying abortion services in the cases provided by law can put at risk the physical and mental health of women and girls who are suffering. It can be considered as torture and cruel, inhumane and degrading treatment." (“Agências da ONU,"2017).

6 The three exceptions are in case of risk of death to the pregnant woman and pregnancy from rape or an anencephalic fetus.

\section{Mirla Cisne}

mirlacisne@gmail.com

Doctor of Social Work from Universidade do Estado do Rio de Janeiro (UERJ)

Assistant Professor of Social Work at the Universidade do Estado do Rio Grande do Norte (UERN)

\section{Giulia Maria Jenelle Cavalcante de Oliveira}

giuliamjco@gmail.com

Bachelor of Laws from Universidade do Estado do Rio Grande do Norte (UERN)

Lawyer and Master's candidate in Social Work and Social Rights from Universidade do Estado do Rio Grande do Norte (UERN)

\section{Viviane Vaz Castro}

vivianevazcastro91@gmail.com

Master's degree in Social Work and Social Rights from Universidade do Estado do Rio Grande do Norte (UERN)

Substitute Professor of Social Work at the Universidade do Estado do Rio Grande do Norte (UERN)

\section{UERN}

Av. Professor Antônio Campos, s/n

Mossoró - Rio Grande do Norte - Brazil

CEP: $59.625-620$

\section{Funding}

Not applicable.

\section{Authors' contributions}

Mirla Cisne - responsible for the theoretical framework about the patriarchy categories, the sexual division of labor, sexage, appropriation and the perspective of the consubstantiality and coextensivity in social relations of sex, race, and class. Also responsible for the general revision and text formatting. Viviane Castro - responsible for the introduction and the historical debate on abortion, as well as the bibliographic and documental research on the topic. Giulia Cavalcante - responsible for the social-legal analysis and the political challenges for the legalization of abortion in the current context. Also responsible for the final revision. The abstract and the conclusion were prepared by the three authors together.

Ethics approval and consent to participate Not applicable.

\section{Consent for publication}

Not applicable.

\section{Competing interests}

There are no competing interests. 